\title{
EMPOWERMENT OF THE INSTITUTIONAL-MANAGERIAL STRUCTURE BY URBAN SUSTAINABLE DEVELOPMENT APPROACH AND FUZZY QSPM
}

\author{
Kimia Moazeni
}

Original scientific paper Most today's cities are faced with many institutional and managerial problems, including lack of integration of administrative and regulatory agencies dealing with metropolitan issues, similar approaches to urban management in servicing residents of various localities, lack of efficient decision-making tools, information and documents. The purpose of this study is to identify and explain the strengths and weaknesses, opportunities and threats (SWOT) points of the institutional-managerial structure of Tehran city and to provide strategies to turning weaknesses into strengths and threats into opportunities in order to empower the institutional-managerial structure of Tehran city. To identify internal strengths and weaknesses as well as external opportunities and threats points, SWOT analysis model is used. Then, this paper applies fuzzy quantitative strategic planning matrix (fuzzy QSPM) to prioritize strategies for empowering the institutional-managerial structure of Tehran city. The results show that the highest priority strategy is "to develop a comprehensive, strategic and long-term plan for sustainable urban development in urban management system".

Keywords: empowerment; fuzzy QSPM; sustainable urban development; Tehran

\section{Davanje većih ovlasti institucionalno-upravljačkoj strukturi primjenom pristupa urbanog održivog razvoja i neizrazite matrice kvantitativnog strateškog planiranja (QSPM)}

Izvorni znanstveni članak

Većina današnjih gradova suočena je s mnogim institucionalnim i upravljačkim problemima, uključujući nedostatak integracije u administrativnim i regulatornim agencijama koje se bave problemima metropole, sličnih pristupa upravljanju gradom kad se radi o pružanju usluga na različitim lokalitetima, nedostatak učinkovitih alata za donošenje odluka, informacija i dokumenata. Cilj ovog istraživanja je da se prepoznaju i objasne snaga i slabosti, mogućnosti i prijetnje (SWOT) institucionalno-upravljačke strukture Teherana i da se pronađu strategije kojima bi se slabosti pretvorile u snagu, a prijetnje u mogućnosti u svrhu davanja većih ovlasti institucionalno-upravljačkoj strukturi Teherana. Kako bi se prepoznala unutarnja snaga i slabosti kao i vanjske mogućnosti i prijetnje, primijenjen je model SWOT analize. U radu se zatim primjenjuje neizrazita matrica kvantitativnog strateškog planiranja (fuzzy QSPM) kako bi se dalo prvenstvo strategijama za davanje ovlasti institucionalno-upravljačkim strukturama Teherana. Rezultati pokazuju da se najveća prednost daje strategiji "za razvoj sveobuhvatnog, strateškog i dugoročnog plana održivog urbanog razvoja u sustavu upravljanja gradom".

Ključneriječi: jačanje ovlasti; neizraziti QSPM; održivi urbani razvoj; Teheran

\section{Introduction}

During recent years, scientific schools and official institutions have been concerned with sustainability in urban development. All definitions related to sustainability are discussed by taking into account the bearing capacity of the environment to meet the needs of the present generation without posing limitations on facilities of the future generation to meet their needs. Besides, the idea of sustainability is a concept considering five environmental, social, economic, physical and institutional-managerial factors simultaneously [1]. This theory discusses problems such as prevention of urban and regional environmental pollution, reduction of local, regional and national production capacities, support for tissues and lack of support for detrimental developments, and elimination of the gap between rich and poor [2]. According to this theory, the only way to achieve these goals is urban planning, say, land use control and more urban control. This theory, as a strategic vision, underlines the role of government in this planning. This theory believes that the government should support the urban environment. The sustainable urban development improves long-term social and ecologic health of the cities. Accordingly, the main directions of urban sustainability need to cover areas such as restoration of naturally and locally ecological systems, sustainable economy, compact land-use with higher efficiency, the lesser personal vehicle the easier access, correct usage of resources, preservation of local culture, public and spontaneous participation, healthy social ecology, housing and a suitable living environment [3].

In the urban management structure, interaction and communication within and between institutions are considered as a lever to improve organizational performance [4]. Many current urban management inefficiencies, especially in the third world and developing countries (including Tehran), are not due to increased number of institutions, but to poor organizational and institutional synergy, which leads to increased urban challenges and poorly responsive urban management to several problems such as poverty, unemployment, social disorder, moral density, social gap, traffic and lack of services [5]. Substitution of institutional interaction by institutional conflict in microand macro-scale urban management leads to the decreased effectiveness of urban management practices in implementation phase, even with the best goal and plan. Because micro-and macro-scale urban planning requires the engagement and integration of all managerial (public and private) sectors to implement developed plans along each other (by maintaining institutional independence) [6]. However, the reason of weak managerial synergy is centralized structure of urban management and absence of many stakeholders and influential members in the urban management process. Nevertheless, institutional divergence of urban management in the form of empowerment should be considered as one of the main reasons for low effectiveness of interventions, because the nature of empowerment is harmonization, integration and 
synergized interventions for sustainable urban development.

The remaining parts of the current paper are structured as follows: Section 2 presents theoretical framework. Section 3 describes the materials and methods. Section 4 describes the empirical case study. In Section 5, the results of research are presented. Finally, conclusion part of the present paper is presented in Section 6.

\section{Theoretical framework \\ 2.1 Sustainable development of urban management institutions}

The UN Stockholm Conference in 1972 emphasized the environmental discussions, particularly those associated with environmental degradation and overseas pollution. Environmental degradation in both developing and developed countries can influence a variety of social, economic and political interests throughout the world as a whole. International recognition to the fact that environmental protection and natural resource management should solve socioeconomic problems, poverty and underdevelopment have been increasingly concerned in the Rio Earth Summit in 1992 [7]. This idea is inspired by the definition of 'sustainable development' by the World Commission on Environment and Development -Brantl and Commission- in 1987 known as 'the development which meets requirements of the present generation without compromising the abilities of future generations to meet their own needs'. It has been recently recognized that environmental, social and economic considerations are completely interlinked. In the urban context, this means that sustainable urban development is not an option but a necessity. If cities are to meet the needs of the citizens and if cities are indeed future home of humanity, urban centres, in this case, need to be socially fair, economically successful and environmentally sustainable [8].

Efforts of sustainable urban management focus on sustainability of resources for future generations and avoidance of wasting resources along with the achievement of an acceptable level of public services and urban welfare for all generations. Efficient and sustainable urban management needs to plan, make policies for, direct, organize, supervise and coordinate all local affairs of urban system [9]. Urban management should be required to follow goals such as sustainable and humanistic views over the city and eventually policies of good governance such as fairness, transparency, accountability, public comments, participation, etc., therefore, integrated urban management is the start point in urban sustainability, not a long-term vision and goals of the urban management. The key problem is how to empower the foundations of local institutions and civil society [10].

\subsection{Institutional-managerial empowerment}

The empowerment approach is considered as one of the results of governance and (urban) integrated management and underlies it. Explanation of the empowerment concept for the management can be likened to the human body [11]. Human is a weighted combination of distinctive organs. Due to interdependence of various organizations and management institutions in different geographical areas, these institutions should be considered as members of the human body and organizational and communicational culture. Urban management system is successful when its managerial institutions can establish coordination between separate and independent units and between other management institutions. This is a task and even an art which is recently considered as a mission of leadership [12]. Hence, empowerment is a new and important problem in managerial sciences, essentiality of which in the management system can be summarized in the following five elements:

1) Empowerment of urban organizations to help coordinate distribution of activities and to increase balance.

2) Coordination of activities and avoidance of uneven distribution of activities upon other managerial institutions and organizations to prevent failure of activities.

3) Empowerment which leads to the prevention of different crises within the organization or organizational relationships.

4) Crises caused in institutions are often upon certain parts (without any coordination and vision systems); threatening a certain part is not only detrimental, but also leads to inefficient performance of that part. Therefore, empowerment avoids this crisis by coordination.

5) Empowerment increases overall efficiency, prevents confusion of sectors and increases institutional strength [13].

Therefore, institutional-managerial empowerment is a system of convergent participation, which collaborates in thought mechanism or a group of managements to achieve managerial goals and required coordination [14].

Institutional empowerment integrates professional and dynamic coalitions between and among state bureaucracy and various actors of civil society. The middle level of institutional empowerment is related to the type of interaction and communications between urban formal and informal institutions (local communities, etc.) [15]; this occurs under the form of a series of horizontal and synergic communications, which promote a dynamic, efficient and effective urban management structure.

\section{Materials and methods}

\subsection{Delphi technique}

Delphi is a new method used in studies related to planning. Due to the lack of a final approach to research and the lack of a statistical basis for conclusions, one can present a stepwise methodology for urban research. Delphi survey is independent of the sample representative of the population. Delphi is a group decision mechanism which involves the participation of decent experts understanding the subject [16]. Therefore, one of the most important requirements is to select the appropriate experts. 
The group of academic scholars and experts in urban management included 23 experts selected by snowball technique. According to the guidelines of Delbecq et al. [16], this study used a multi-step approach to identify experts:

- Step 1: Preparing a worksheet of candidate knowledge resources

- Step 2: Filling out the worksheet by names

- Step 3: The first round of calls, nominating other experts

- Step 4: Ranking experts based on attributes

- Step 5: Inviting experts to the study

Procedure: In this study, the research procedure involved Delphi scoring system to administer questionnaires. The procedures included three general steps: 1 . brainstorming for determination of criteria and sub-criteria, 2. limiting the main list to the most important criteria and 3. Weighing the list of important criteria and sub-criteria [17].

\subsection{SWOT}

The main objective of this step is a conversation with internal key decision-makers to reach agreement on the overall strategic planning process. This agreement guarantees cases such as determining priorities of planning process, scheduling reports, roles, functions and composition of strategic planning group members as well as providing the resources necessary to achieve the expected goals $[18,19]$.

- Internal Factor Evaluation. The area evaluation is conducted to identify its strengths and weaknesses as a part of controllable activities, which benefit or harm the area at any time. Internal factor evaluation process is in parallel with the external factor evaluation [20].

- External Factor Evaluation. This step explains and describes the external environment to identify opportunities and threats faced by the institutions and urban management. In this regard, political, economic, social and technological trends and events are evaluated by the nature and position of different groups such as stakeholders, citizens, investors and other factors that can greatly benefit or harm the considered area in the future [20].

- Four Formulated Strategies. At this stage, strategies were developed for those identified in earlier stages. The strategy development process began with determination of executable alternatives and ideas or approaches to problem solving. Each of the four factors of SWOT was analysed after identification. The SWOT matrix was formed in the next step. Then, the four factors were prioritized based on the questionnaire and according to experts and officials of urban management.

\subsection{Fuzzy QSPM}

Unlike classic logic, the fuzzy logic is a useful material to solve problems related to complex systems, which are difficult to understand or problems associated with reasoning, decision-making and human inferences
$[21 \div 25]$. Quantitative strategy planning matrix (QSPM) is used to evaluate the feasibility and sustainability of fuzzy solutions proposed under urban management conditions of Tehran and to characterize relative attractiveness of strategies used in the decision-making process. Final strategies were initially selected by prioritizing acceptable strategies of the previous step. If a strategy lacked optimal internal and external conditions for empowerment of urban management of Tehran, it would be excluded from the list of prioritizable strategies [26].

\section{$4 \quad$ Empirical case study}

Tehran is the largest city and the capital of Iran and the centre of Tehran Province. Totally, 8244535 people live in Tehran as the eighteenth most populous city in the world. The city has an area of $730 \mathrm{~km}^{2}$. To provide requirements and for a better management, municipality of Tehran divided it to 22 municipality regions and 123 areas, including Shahre Rey and Tajrish (Tehran Municipality [27]) (Fig. 1).

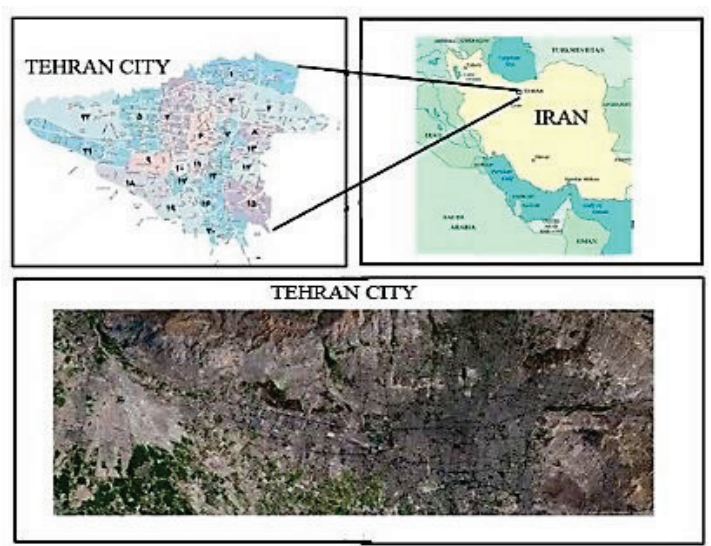

Figure 1 The studied area

Here is a review of the most important management institutions in Tehran.

Tehran Municipality is aware of the problems of the citizens more than the City Council is; it is also more qualified to manage the city. However, the city council has a greater influence on the final decision than municipality does in case of conflict between policymaking bodies. In total, the City Council plays a finer role in macroeconomic policies than the municipality. Participation of the city council is not sufficiently robust for policy-making because of excluding many essential urban discussions such as transportation, land, housing and economic development policies. Even according to experts and managers of urban policy making, the city council is not enough strong to participate in the urban management as a major institution of policy making.

In case of conflict between policy-makers, the municipality has less power to influence the final decision. Compared to government bodies and even the private sector, municipality has fewer resources. In contrast with highlighted role of government followed by private institutions, the role of municipality is negligible.

Government and state institutions of Tehran are, to a lesser degree, informed of the fundamental problems of citizens compared to the urban management. They are 
less responsible for management of Tehran while at the same time they contribute most in policy making. Most of the financial resources are available for this group. Instead of costly, time-consuming, and non-economic activities like policymaking and providing required infrastructure of Tehran or transportation, they are interested in strategic issues such as economic development, physical development, land use and housing. In this regard, they actively act as the final decision-makers in the case of conflict in policymaking; this results from a concentrated system of management in which the central government is responsible for the final decision. While in non-concentrated systems, the power of the central government is distributed among local governments by election. The final decision is a product of interaction between shareholders.

\section{Results}

Planning in any space is impossible regardless of the circumstances and elements forming that space. For an efficient and effective analysis of factors, it is essential to be aware of the studied structure which is internal and external environment. It is also necessary to have a full understanding about the effect of these factors in order to define consciously the empowerment strategies [28, 29]. This step involves evaluating the external and internal environment. Small decisions taken at the input stage allow programmers to develop different strategies in effective ways. Recognition of the content and nature of information can be the most important activity on this part. Tabs. 1 and 2 illustrate the internal and external factors.

Table 1 Internal factor evaluation

\begin{tabular}{|c|c|}
\hline \multicolumn{2}{|c|}{ Internal factors } \\
\hline Strengths & Weaknesses \\
\hline $\begin{array}{l}\text { 1S. Tendency to support civic and } \\
\text { non-governmental } \\
\text { organizations } \\
\text { 2S. Activeness and tendency of } \\
\text { boards to respond quickly to } \\
\text { the longstanding needs of } \\
\text { people } \\
\text { 3S. Housing and Urban } \\
\text { Development and Governor } \\
\text { in the City } \\
\text { 4S. Institutional and regulatory } \\
\text { contexts and incentive system } \\
\text { required for improvement and } \\
\text { modernization of } \\
\text { deteriorating urban areas } \\
\text { 5S. relative grounds of public } \\
\text { participation in urban } \\
\text { governance } \\
\text { 6S. specialist companies for } \\
\text { spatial planning and urban } \\
\text { development in the region } \\
\text { 7S. Thinking and attitudes based } \\
\text { on area in structure of urban } \\
\text { management } \\
\text { 8S. Communication and } \\
\text { interaction between } \\
\text { municipality, the City } \\
\text { Council and the people in the } \\
\text { level of urban } \\
\text { neighbourhoods }\end{array}$ & $\begin{array}{l}\text { 1W. ignoring implementation of } \\
\text { projects and municipal } \\
\text { earnings and resources } \\
\text { 2W.number of determining } \\
\text { organizations } \\
\text { 3W.time-consuming process of } \\
\text { developing urban } \\
\text { development projects } \\
\text { 4W. Weak executive and } \\
\text { regulatory organizations on } \\
\text { urban problems } \\
\text { 5W. local unplanned projects } \\
\text { regardless of macro vision } \\
\text { 6W. Similar approaches to urban } \\
\text { management in servicing } \\
\text { residents of various localities } \\
\text { 7W. High costs due to the } \\
\text { inconsistencies between } \\
\text { related organizations }\end{array}$ \\
\hline
\end{tabular}

\subsection{Internal Factor Evaluation (IFE) and External Factor Evaluation (EFE) matrix}

Considering defects of SWOT analysis, some methods are combined by SWOT to enhance its performance. SWOT factors were listed by participation of experts and academic authorities in the form of Likert; the relative weight of each factor was calculated using the Eqs. (1) and (2).

$$
\begin{aligned}
& R_{i j}=\sum S_{i} F_{i}, \\
& Y_{i j}=\frac{R_{i j}}{\sum R_{i j}},
\end{aligned}
$$

where, $R_{i j}$ is the variable rate of $j$ in group $i$; $S_{i}$ is Likert's score in five categories; $F_{i}$ is frequency of alternatives; $Y_{i j}$ is final weight of the $j^{\text {th }}$ factor in group $i$.

\begin{tabular}{|c|c|}
\hline \multicolumn{2}{|c|}{ External factors } \\
\hline Opportunities & Threats \\
\hline $\begin{array}{l}\text { 1O. Appropriate legal and } \\
\text { institutional basis for } \\
\text { integrated urban management } \\
\text { 2O. Centralized government and } \\
\text { easier implementation of } \\
\text { executive plans } \\
\text { 3O. Willingness of citizens to } \\
\text { contribute to the urban affairs } \\
\text { (consequently improving their } \\
\text { lives) } \\
\text { 4O. Suitable contexts for the } \\
\text { development of non- } \\
\text { governmental organizations } \\
\text { (NGO) as an effective and } \\
\text { executive mechanism for } \\
\text { public participation } \\
\text { 5O. tendency to structured } \\
\text { strategic planning of urban } \\
\text { development } \\
\text { 6O. Comprehensive systemic } \\
\text { approaches in urban planning } \\
\text { and management instead of } \\
\text { local attitudes in structured } \\
\text { strategic planning of urban } \\
\text { development } \\
\text { 7O. Increased attention of urban } \\
\text { management to sustainable } \\
\text { urban development } \\
\text { 80. Changing attitudes from } \\
\text { physical pattern to human } \\
\text { pattern in urban management }\end{array}$ & $\begin{array}{l}\text { 1T. Short term urban } \\
\text { management planning and } \\
\text { lack of a long term strategic } \\
\text { plan for sustainable } \\
\text { development } \\
\text { 2T. Failure to monitor the } \\
\text { activities of the consulting } \\
\text { producers of urban } \\
\text { development projects } \\
\text { 3T. Inconsistencies between } \\
\text { effective organizations in } \\
\text { planning and management of } \\
\text { urban development } \\
\text { 4T. Poor executive organizations } \\
\text { regarding the absence of } \\
\text { specific rules and inefficiency } \\
\text { of existing regulations } \\
\text { 5T. dominance of abusive and } \\
\text { sectional thinking instead of } \\
\text { long-term, prospective, social } \\
\text { development }\end{array}$ \\
\hline
\end{tabular}

Table 2 External factor evaluation

This method is integrated with SWOT to quantify the SWOT factors and to enable assessment of the relative importance of each factor and the overall assessment of decision-making positions (Tabs. 3 and 4).

\subsection{Strategy development}

The results of prioritizing strengths, weaknesses, opportunities and threats as well as experts' evaluation of SWOT factors in the form of relative weighing method demonstrates that the most important strength is S4, 'Institutional and regulatory contexts and incentive system required for improvement and modernization of deteriorating urban areas (relative weight 0,165). In addition, the weakness factor was W4, 'Weak executive 
and regulatory organizations on urban problems'. In relation to opportunities, $\mathrm{O} 6$ has the highest relative weight between both opportunities and SWOT factors (relative weight: 0,163). Moreover, T2 is the highest priority with the highest relative weight and the second priority among SWOT factors.

- Strategy Formulation (Comparison Phase). The SWOT matrix and IFE and EFE matrices are used to develop potential strategies for planning.

- Formulation of SO Strategies. In this strategy, the institutional-managerial structure of Tehran demands a situation where they are able to maximize their strengths and opportunities. Unlike the defensive strategy which is a reactive solution, invasive strategy is an actor solution.

- Formulation of WO Strategies. Purpose of WO strategies is to improve internal weaknesses by exploiting the opportunities in the external environment. Sometimes outside the institutionalmanagerial structure, there are very good opportunities, which are difficult to exploit due to the internal weaknesses.

- Formulation of ST Strategies. This strategy is based on taking advantage of the strengths of institutionalmanagerial structure to counter the threats in order to maximize the strengths and minimize the threats. However, experiences show that inappropriate usage of power can bring undesirable results; thus, no planning should use unreflectively its power to eliminate threats.

- Formulation of WT Strategies. WT strategies are the most conservative strategies to minimize internal weaknesses and avoid threats from the external environment [30,31].

The SWOT matrix compares two factors in one step, not to identify the best strategy, but to determine the executable strategies; therefore, all strategies presented in SWOT matrix will not be selected and implemented (Tab. $5)$.

Table 3 Weighted score, relative weight and priority of internal factors

\begin{tabular}{|c|c|c|c|c|c|c|c|c|}
\hline Rank & Strengths & Relative weight & Score & Final score & weaknesses & Relative weight & Score & Final score \\
\hline 1 & S4 & 0,165 & 3,000 & 0,496 & W4 & 0,183 & 1,000 & 0,183 \\
\hline 2 & S7 & 0,153 & 2,000 & 0,306 & W6 & 0,172 & 1,000 & 0,172 \\
\hline 3 & S1 & 0,149 & 4,000 & 0,595 & W7 & 0,154 & 3,000 & 0,462 \\
\hline 4 & S2 & 0,140 & 4,000 & 0,562 & W5 & 0,142 & 4,000 & 0,568 \\
\hline 5 & S 8 & 0,136 & 3,000 & 0,409 & W1 & 0,134 & 4,000 & 0,536 \\
\hline 6 & S3 & 0,095 & 3,000 & 0,285 & W3 & 0,112 & 2,000 & 0,224 \\
\hline 7 & S6 & 0,093 & 3,000 & 0,279 & W2 & 0,103 & 1,000 & 0,103 \\
\hline 8 & S5 & 0,068 & 1,000 & 0,068 & & & & \\
\hline
\end{tabular}

Table 4 Weighted score, relative weight and priority of external factors

\begin{tabular}{|c|c|c|c|c|c|c|c|}
\hline Opportunities & Relative weight & Score & Final score & threats & Relative weight & Score & Final score \\
\hline O6 & 0,163 & 4,000 & 0,652 & T2 & 0,198 & 2,000 & 0,396 \\
\hline O3 & 0,152 & 4,000 & 0,608 & T1 & 0,182 & 2,000 & 0,364 \\
\hline O1 & 0,147 & 4,000 & 0,588 & T5 & 0,179 & 1,000 & 0,179 \\
\hline O2 & 0,142 & 4,000 & 0,568 & T4 & 0,167 & 1,000 & 0,167 \\
\hline O5 & 0,133 & 2,000 & 0,266 & T6 & 0,158 & 1,000 & 0,158 \\
\hline O8 & 0,107 & 1,000 & 0,107 & T3 & 0,116 & 3,000 & 0,348 \\
\hline O4 & 0,095 & 3,000 & 0,285 & & & & \\
\hline O7 & 0,061 & 1,000 & 0,061 & & & & 1,612 \\
\hline Total & 1,000 & & 3,135 & total & 1,000 & & \\
\hline
\end{tabular}

Table 5 Strategies for Empowering the institutional-managerial structure of Tehran

\section{Strategies (SO)}

SO1. Internalizing social partnerships between city managers and citizens

SO2.Public participation in government and supporting councils and public bodies community-centered approach

SO3.Developing rules and regulations of electronic governance and the use of new technologies in the city

SO4.Strengthening the humanity-rather than the body-centered perspectives on urban management

\section{Strategies (WO)}

WO1.Integrated urban management and avoidance of overlapping tasks of organizations in two structural and processing levels

WO2.Strengthening of NGOs as an effective mechanism for social partnership between city managers and citizens

WO3. Strengthening realism, flexibility and mobility of urban projects by broad citizen participation

\subsection{Internal and External Matrix (IE)}

This matrix is used to determine the overall status of strategies. Preparation of IE matrix of the previous reviews allows prediction of expected effects of strategic decisions on the institutional-managerial structure. IE

\section{Strategies (ST)}

ST1.Development of a comprehensive, strategic and long-term sustainable development of the urban management system

ST2. Establishment of a coherent and hierarchical structure in the planning and management of development

ST3.Substitution of the centralized top-down development by down-up development in national development plans

ST4.Effective coordination between agencies involved in planning and managing urban development

\section{Strategies (WT)}

WT1.Increasing and strengthening administrative and regulatory agencies WT2. Establishment of urban management

WT3.Elimination of legal and institutional barriers which impede the urban improvement by efficient development of rules and regulations

WT4.Implementation of an integrated, comprehensive and updated management system of Tehran

matrix can be divided into four regions each of which can use different strategies (Fig. 2).

Values derived from mean final scores of IE matrix which are respectively 2,62 and 2,37 show that the studied factors are in the second region; therefore, 
according to the description and analysis, ST strategies can be implemented for them.

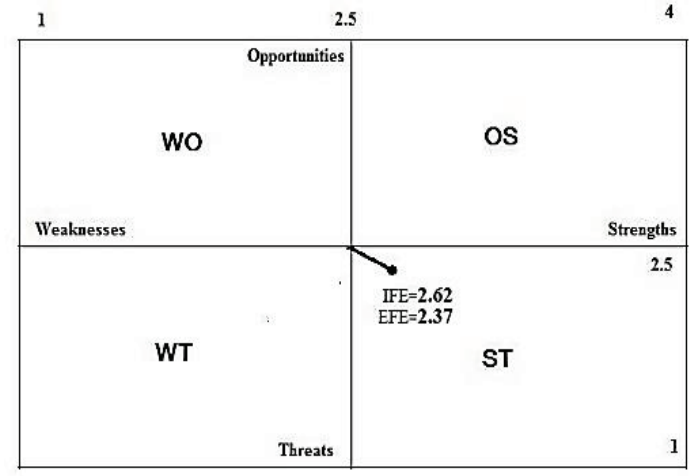

Figure 2 Final score of IFE and EFE matrix

\subsection{Applying the Fuzzy QSPM (Decision-Making Phase)}

By prioritizing acceptable strategies obtained in the previous step, the final strategies were selected by intuitive judgment. The final score of factors was determined by fuzzy QSPM matrix. Analyses of the first step and results from comparison of internal and external factors in the second step were used to implement QSPM by which objective methods of implementable strategies were determined (David et al. 2009: 48).
QSPM was used to determine attractiveness level of the developed strategies. Using QSPM, various strategies, which are the best strategies, could be objectively determined.

Attractiveness scores needed to be particularly assigned to a strategy considering relative attractiveness of the other strategy. Attractiveness scores and effectiveness of the factor $\left(E_{i j}\right)$ are as follows [32]: very low effect $(0 ; 0 ; 0.3)$, low effect $(0 ; 0,3 ; 0,5)$, average effect $(0,2 ; 0,5 ; 0,8)$, high effect $(0,5 ; 0,7 ; 1)$ and very high effect $(0,7 ; 1 ; 1)$.

- Calculating the total score of a strategy. Weighted score of a row is multiplied by attractiveness score of a strategy. Then for each strategy, all products are summed and listed in the sum row, under the related strategies.

$\bar{R}_{J}=\sum_{i=1}^{m+n} E_{i j} \otimes W_{i}=\left(c_{j}, a_{j}, d_{j}\right)$.

There are various methods to defuzzify the fuzzy numbers. In this paper, one of these methods are applied and calculated as the total score $\left(R_{j}\right)$ of each strategy. Higher total score means a higher priority and attractiveness of that strategy.

$R_{j}=\frac{c_{j}+4 a_{j}+d_{j}}{6}$

Table 6 The results of applying fuzzy QSPM

\begin{tabular}{|c|c|c|c|c|c|c|c|c|c|}
\hline Strategy & & & Strategy 1 & & Strategy 2 & & Strategy 3 & & Strategy 4 \\
\hline 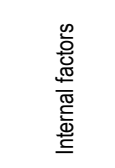 & 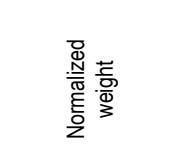 & 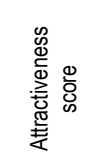 & 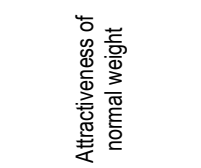 & 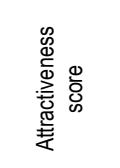 & 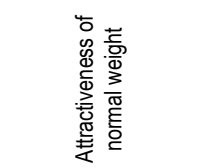 & 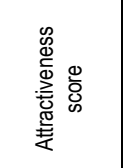 & 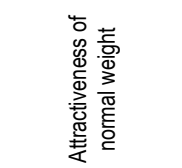 & 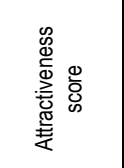 & 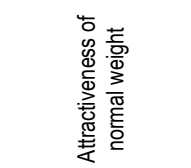 \\
\hline S1 & $(0 ; 0 ; 0)$ & - & $(0 ; 0 ; 0)$ & - & $(0 ; 0 ; 0)$ & - & $(0 ; 0 ; 0)$ & - & $(0 ; 0 ; 0)$ \\
\hline S2 & $(0,963 ; 1,391 ; 1,605)$ & $(0,7 ; 1 ; 1)$ & $(0,674 ; 1,391 ; 1,605)$ & $(0 ; 0,3 ; 0,5)$ & $(0 ; 0,417 ; 0,802)$ & $(0 ; 0 ; 0,3)$ & $(0 ; 0 ; 0,481)$ & $(0,7 ; 1 ; 1)$ & $(0,674 ; 1,391 ; 1,605)$ \\
\hline S3 & $(1,746 ; 2,716 ; 3,398)$ & $(0,7 ; 1 ; 1)$ & $(1,222 ; 2,716 ; 3,298)$ & $(0,5 ; 0,7 ; 1)$ & $(1,901 ; 3,298 ; 0,873)$ & $(0,5 ; 0,7 ; 1)$ & $(1,901 ; 3,298 ; 0,873)$ & $(0 ; 0 ; 0,3)$ & $(0 ; 0 ; 0,989)$ \\
\hline S4 & $(0 ; 0 ; 0)$ & - & $(0 ; 0 ; 0)$ & - & $(0 ; 0 ; 0)$ & - & $(0 ; 0 ; 0)$ & - & $(0 ; 0 ; 0)$ \\
\hline S5 & $(0,226 ; 0,59 ; 0,944)$ & $(0,5 ; 0,7 ; 1)$ & $(0,118 ; 0413 ; 0,944)$ & $(0,5 ; 0,7 ; 1)$ & $(0,118 ; 0,413 ; 0,944)$ & $(0,5 ; 0,7 ; 1)$ & $(0,118 ; 0,413 ; 0,944)$ & $(0 ; 0 ; 0,3)$ & $(0 ; 0 ; 0,283)$ \\
\hline S6 & $(0,948 ; 1,422 ; 2,133)$ & $(0,7 ; 1 ; 1)$ & $(0,663 ; 1,422 ; 2,133)$ & $(0 ; 0,3 ; 0,5)$ & $(0 ; 0,426 ; 1,066)$ & $(0,2 ; 0,5 ; 0,8)$ & $(0,711 ; 1,706 ; 0,189)$ & $(0,5 ; 0,7 ; 1)$ & $(0,474 ; 0,995 ; 2,133)$ \\
\hline S7 & $(0 ; 0 ; 0)$ & - & $(0 ; 0 ; 0)$ & - & $(0 ; 0 ; 0)$ & - & $(0 ; 0 ; 0)$ & - & $(0 ; 0 ; 0)$ \\
\hline S8 & $(1,32 ; 3,3 ; 4,62)$ & $(0,5 ; 0,7 ; 1)$ & $(0,66 ; 2,31 ; 4,62)$ & $(0,7 ; 1 ; 1)$ & $(0,924 ; 3,3 ; 4,62)$ & $(0,2 ; 0,5 ; 0,8)$ & $(0,264 ; 1,65 ; 3,696)$ & $(0,2 ; 0,5 ; 0,8)$ & $(0,264 ; 1,65 ; 3,696)$ \\
\hline $\mathrm{T1}$ & $(3,072 ; 3,84 ; 4,608)$ & $(0,7 ; 1 ; 1)$ & $(2,15 ; 3,84 ; 4,608)$ & $(0 ; 0,3 ; 0,5)$ & $(0 ; 1,152 ; 2,304)$ & $(0 ; 0 ; 0,3)$ & $(0 ; 0 ; 1,683)$ & $(0,2 ; 0,5 ; 0,8)$ & $(0,614 ; 1,92 ; 3,686)$ \\
\hline T2 & $(0 ; 0 ; 0)$ & - & $(0 ; 0 ; 0)$ & - & $(0 ; 0 ; 0)$ & - & $(0 ; 0 ; 0)$ & - & $(0 ; 0 ; 0)$ \\
\hline T3 & $(3,072 ; 3,84 ; 4,608)$ & $(0,7 ; 1 ; 1)$ & $(2,15 ; 3,84 ; 4,608)$ & $(0 ; 0,3 ; 0,5)$ & $(0 ; 1,152 ; 2,304)$ & $(0 ; 0 ; 0,3)$ & $(0 ; 0 ; 1,683)$ & $(0,2 ; 0,5 ; 0,8)$ & $(0,614 ; 1,92 ; 3,686)$ \\
\hline $\mathrm{T} 4$ & $(0 ; 0 ; 0)$ & - & $(0 ; 0 ; 0)$ & - & $(0 ; 0 ; 0)$ & - & $(0 ; 0 ; 0)$ & - & $(0 ; 0 ; 0)$ \\
\hline T5 & $(0,393 ; 0,655 ; 1,048)$ & $(0,7 ; 1 ; 1)$ & $(0,275 ; 0,655 ; 1,048)$ & $(0,2 ; 0,5 ; 0,8)$ & $(0,079 ; 0,327 ; 0,838)$ & $(0 ; 0 ; 0,3)$ & $(0 ; 0 ; 0,3)$ & $(0,2 ; 0,5 ; 0,8)$ & $(0,079 ; 0,327 ; 0,838)$ \\
\hline T6 & $(1,312 ; 0,328 ; 0,82)$ & $(0 ; 0,3 ; 0,5)$ & $(0 ; 0,246 ; 0,656)$ & $(0,5 ; 0,7 ; 1)$ & $(0,164 ; 0,574 ; 1,312)$ & $(0,7 ; 1 ; 1)$ & $(0,229 ; 0,82 ; 1,312)$ & $(0,5 ; 0,7 ; 1)$ & $(0,164 ; 0,574 ; 1,312)$ \\
\hline \multicolumn{3}{|c|}{ Total Fuzzy scores of Strategies } & $(8,172 ; 18,625,27,525)$ & & $(2,903 ; 11,432 ; 20,578)$ & & $(2,131 ; 8,55 ; 17,761)$ & & $(3,497 ; 10,579 ; 22,001)$ \\
\hline \multicolumn{3}{|c|}{ Defuzzified score of strategies } & 18,366 & & 11,535 & & 9,015 & & 11,302 \\
\hline \multicolumn{3}{|c|}{ Priority of strategies } & 1 & & 2 & & 4 & & 3 \\
\hline
\end{tabular}

Tab. 6 shows a QSPM obtained from calculations of this study. It is noteworthy that four strategies outlined in this section are derived from the analysis and synthesis of internal and external factors.

According to the matrix of internal and external factors, ST strategies are selected for institutionalmanagerial structure of Tehran, as follows:

1. Developing a comprehensive, strategic and long-term plan for sustainable development of the urban management system $(18,366)$

2. A coherent and hierarchical structure in the planning and management of urban development $(11,535)$
3. Effective coordination between agencies involved in the planning and management of urban development $(11,302)$

4. Substitution of the centralized top-down development by down-up development in national development plans $(9,015)$

According to calculations and based on findings listed in Table 6, the first strategy, 'Developing a comprehensive, strategic and long-term plan for sustainable development of the urban management system' is selected as the strategy of choice for empowerment of the institutional-managerial structure of Tehran by sustainable urban development approach. 
According to the obtained results, the proposed policies to strengthen institutional-managerial structure of Tehran include:

- Establishment of a coherent and hierarchical structure in the planning and management of development

- Integrated urban management and avoidance of overlapping tasks of organizations in two structural and processing levels

- Public participation in urban management and support of councils and public bodies by a community-centered approach

- Substitution of strategic-structural plans of urban development by SDI projects

- Increasing and strengthening administrative and regulatory agencies

- Strengthening urban management system by recruiting experts of urban development

- Effective coordination between agencies involved in planning and managing urban development

- Development of a comprehensive, strategic and longterm sustainable development of the urban management system

- Implementation and development of municipal and provincial development plans, in coordination with the urban sustainable development

- Strengthening of NGOs as an effective mechanism for social partnership between city managers and citizens

- Elimination of legal and institutional barriers which impede the urban improvement by efficient development of rules and regulations

- Avoiding selective collisions in urban neighbourhoods and guaranteeing the rights of citizens

- Implementation of an integrated, comprehensive and updated management system of Tehran

- Preparation of special projects for the integrated development of urban neighbourhoods, and aging and deteriorating tissues

- Strengthening the humanity-rather than the bodycantered perspectives on urban management

- Developing rules and regulations of electronic governance and the use of new technologies in the city

- Strengthening realism, flexibility and mobility of urban projects by broad citizen participation

- Substitution of the centralized top-down development by down-up development in national development plans.

\section{Conclusions}

Institutions and organizations are continuously seeking the solutions for improving their empowerment. Hence, it is necessary to understand the status quo through evaluation of internal and external factors for any decision-making and strategic planning in the organization. Environmental analysts are responsible for accurate evaluation of environmental variables on different sectors of the organization, including inputs and outputs, in order to identify opportunities and threats. In other words, opportunities and threats are recognized by environmental analysis based on which and by the identification of internal strengths and weaknesses, the organization sets goals and characterizes procedures and organizational policies. This helps the management to deal with opportunities and threats of the external environment by integrated procedural decisions in order to achieve its goals appropriately.

Tehran experiences many institutional and managerial problems including lack of integration of administrative and regulatory agencies dealing with urban issues, similar approaches to urban management in servicing residents of various localities, lack of efficient decision-making tools, information and documents in the city. After showing the necessity of institutionalmanagerial empowerment in Tehran for an urban sustainable development, the present study used a stepwise approach along with strategic planning materials. After selecting the sample, the IFE and EFE matrices were formed to determine the coefficient of factors and to decide on highly important and less important strategic factors by experts in order to obtain the final score by results from matrices. Results indicate status of institutional-managerial structure of Tehran to external and internal factors. Then, SWOT matrix was formed by a comparative evaluation in the form of WT, ST, WO and ST strategies; afterwards, the highest priority strategies were extracted by QSPM matrix in which the highest priority strategy was the development of a comprehensive, strategic and long-term program for urban sustainable development ( score $=18,366)$.

For future research, other fuzzy multi-criteria decision making models to prioritize strategies for empowering the institutional-managerial structure can be used. To serve as guidance for future research, other criteria can be considered rather than the used criteria. Future studies can also focus on the comparison of the proposed methodology results with existing models in literature.

\section{References}

[1] Li, F.; Liu, X.; Hu, D.; Wang, R.; Yang, W.; Li, D.; Zhao, D. Measurement indicators and an evaluation approach for assessing urban sustainable development: A case study for China's Jining City. // Landscape and Urban Planning. 90, 3(2009), pp. 134-142. DOI: 10.1016/j.landurbplan.2008.10.022

[2] Elliott, J. An introduction to sustainable development. Routledge, 2012.

[3] While, A.; Jonas, A. E.; Gibbs, D. From sustainable development to carbon control: eco-state restructuring and the politics of urban and regional development. // Transactions of the Institute of British Geographers. 35, 1(2010), pp. 76-93. DOI: 10.1111/j.1475-5661.2009.00362.x

[4] Ward, K. 'Policies in Motion', Urban Management and State Restructuring: The Trans-Local Expansion of Business Improvement Districts. // International Journal of Urban and Regional Research. 30, 1(2006), pp. 54-75. DOI: 10.1111/j.1468-2427.2006.00643.x

[5] Arefi, M. Towards a conceptual framework for urban management: The Iranian experience. City, Culture and Society, 2013

[6] Akhondzadeh-Noughabi, E.; Alizadeh, S.; Ahmadvand, A. M.; Minaei-Bidgoli, B. FTiS: A new model for effective urban management: A case study of urban systems in Iran. // Cities. 31, 1(2013), pp. 394-403. DOl: 10.1016/j.cities.2012.12.004

[7] Smit, B.; Pilifosova, O. Adaptation to climate change in the context of sustainable development and equity. // Sustainable Development. 8, 9(2003), pp. 9-14. 
[8] Varol, C.; Ercoskun, O. Y.; Gurer, N. Local participatory mechanisms and collective actions for sustainable urban development in Turkey. // Habitat International. 35, 1(2011), pp. 9-16. DOI: 10.1016/.habitatint.2010.02.002

[9] Deakin, M.; Reid, A. Sustainable urban development: Use of the environmental assessment methods. // Sustainable Cities and Society. 10, 1(2014), pp. 39-48. DOl: 10.1016/j.scs.2013.04.002

[10] Woolthuis, R. K.; Hooimeijer, F.; Bossink, B.; Mulder, G.; Brouwer, J. Institutional entrepreneurship in sustainable urban development Dutch successes as inspiration for transformation. // Journal of Cleaner Production. 50, (2012), pp. 91-100. DOI: 10.1016/j.jclepro.2012.11.031

[11] Bontenbal, M. C. Strengthening urban governance in the South through city-to-city cooperation: Towards an analytical framework. // Habitat International. 33, 2(2009), pp. 181-189. DOI: 10.1016/j.habitatint.2008.10.016

[12] Kim, K. S.; Dickey, J. Role of urban governance in the process of bus system reform in Seoul. // Habitat International. 30, 4(2006), pp. 1035-1046. DOl: 10.1016/j.habitatint.2005.09.010

[13] Laquian, A. A. Metropolitan governance reform in Asia. // Public administration and development. 25, 4(2005), pp. 307-315. DOI: 10.1002/pad.384

[14] Smedby, N.; Neij, L. Experiences in urban governance for sustainability. The Constructive Dialogue in Swedish municipalities. // Journal of Cleaner Production. 50, (2012), pp. 148-158. DOI: 10.1016/j.jclepro.2012.11.044

[15] Cook, I. R. Private sector involvement in urban governance: The case of Business Improvement Districts and Town Centre Management partnerships in England. // Geoforum. 40, 5(2009), pp. 930-940. DOl: 10.1016/j.geoforum.2009.07.003

[16] Delbecq, A. L.; Van de Ven, A. H.; Gustafson, D. H., Group Techniques for Program Planning: a Guide to Nominal Group and Delphi Processes. Scott, Foresman, Michigan, 1975.

[17] Miller, F. P.; Vandome, A. F.; McBrewster, J.,Delphi Method: Delphi Method, Forecasting, Median, The Wisdom of Crowds, Wideband Delphi, John Brunner (novelist), DARPA, Policy Analysis Market, Prediction Market. Alphascript Publishing, 2010.

[18] Amin, S. H.; Razmi, J.; Zhang, G. Supplier selection and order allocation based on fuzzy SWOT analysis and fuzzy linear programming. // Expert Systems with Applications. 38, 1(2011), pp. 334-342. DOI: 10.1016/j.eswa.2010.06.071

[19] Rezaie, K.; Ansarinejad, A.; Nazari-Shirkouhi, S.; Karimi, M.; Miri-Nargesi, S. S. A novel approach for finding and selecting safety strategies using SWOT analysis. // In Computational Intelligence, Modelling and Simulation (CIMSiM), 2010 Second International Conference on IEEE. (2010), pp. 394-397.

[20] Roberts, P.; Sykes, H. Urban Regeneration, SAGE Publication, London, UK; 2000.

[21] Azadeh, A.; Shirkouhi, S. N.; Rezaie, K. A robust decisionmaking methodology for evaluation and selection of simulation software package. // The International Journal of Advanced Manufacturing Technology. 47, 1-4(2010), pp. 381-393. DOI: 10.1007/s00170-009-2205-6

[22] Nazari-Shirkouhi, S.; Ansarinejad, A.; Miri-Nargesi, S. S.; Dalfard, V. M.; Rezaie, K. Information systems outsourcing decisions under fuzzy group decision making approach. // International Journal of Information Technology \& Decision Making. 10, 6(2011), pp. 989-1022. DOl: 10.1142/S0219622011004683

[23] Nazari-Shirkouhi, S.; Shakouri, H.; Javadi, B.; Keramati, A. Supplier selection and order allocation problem using a two-phase fuzzy multi-objective linear programming. // Applied Mathematical Modelling. 37, 22(2013), pp. 93089323. DOI: 10.1016/j.apm.2013.04.045
[24] Azadeh, A.; Nazari-Shirkouhi, S.; Hatami-Shirkouhi, L.; Ansarinejad, A. A unique fuzzy multi-criteria decision making: computer simulation approach for productive operators' assignment in cellular manufacturing systems with uncertainty and vagueness. // The International Journal of Advanced Manufacturing Technology. 56, 1-4(2011), pp. 329-343.

[25] Keramati, A.; Nazari-Shirkouhi, S.; Moshki, H.; AfshariMofrad, M.; Maleki-Berneti, E. A novel methodology for evaluating the risk of CRM projects in fuzzy environment. // Neural Computing and Applications. 23, 1(2013), pp. 2953. DOI: $10.1007 / \mathrm{s} 00521-012-1216-7$

[26] David, M. E.; David, F. R. The Quantitative Strategic Planning Matrix (QSPM) Applied to a Retail Computer Store. // The Coastal Business Journal. 8, 1(2009), pp. 4252.

[27] Tehran Municipality. Statistical Yearbook, Tehran; 2011.

[28] Nikolaou, I. E.; Evangelinos, K. I. A SWOT analysis of environmental management practices in Greek Mining and Mineral Industry. // Resources Policy. 35, 3(2010), pp. 226234. DOI: $10.1016 /$ j.resourpol.2010.02.002

[29] Zhao, W.; Watanabe, Ch.; Griffy-Brown, Ch. Competitive advantage in an industry cluster: The case of Dalian Software Park in China. // Technology in Society. 31, 2(2009), pp. 139-149. DOI: 10.1016/j.techsoc.2009.03.008

[30] Golkar, K. Making proper techniques for application in urban design using analytical SOWT. // Sofhe Journal. 41, 2(2005), pp. 51-63.

[31] Eftekhari, A. R.; Mahdavi, D. Development strategies for rural tourism using SWOT, A case study Small Lavasan. // Human Sciences Modares. 10, 2(2006), pp.1-30.

[32] Ghazinoory, S.; Esmail Zadeh, A.; Memariani, A. Fuzzy SWOT Analysis. // Journal of Intelligent \& Fuzzy Systems. 18, 1(2007), pp. 99-108.

\section{Author's address}

Kimia Moazeni

Department of Art and Architecture,

South Tehran Branch, Islamic Azad University,

Tehran, Iran

E-mail: kimia.moazeni@live.com 